\title{
Neocyclops Gurney from Brazilian sandy beaches (Copepoda: Cyclopoida)
}

\author{
Guilherme Ribeiro Lotufo \& Carlos Eduardo Falavigna da Rocha \\ Departamento de Zoologia, Instituto de Biociências, Universidade de São Paulo, Caixa Postal 20520, \\ 01498 - São Paulo, Brazil
}

Keywords: Taxonomy, Crustacea, Cyclopoida, Neocyclops, interstitial marine fauna, Brazil

\begin{abstract}
Neocyclops medius Herbst, 1955 and Neocyclops vicinus (Herbst, 1955) are redescribed from intertidal interstitial water of sandy beaches along the Brazilian coast. The male of $N$. vicinus is described for the first time.

Neocyclops vicinus can be easily distinguished from $N$. medius by the relatively longer caudal rami, the presence of a mandibular palp, and the sexually dimorphic antenna.

This study revealed the leg 4 endopodite segments 2 and 3 as being fused in both species. The terminal segment of the 2-segmented leg 4 endopodite of the copepodite 5 does not differentiate into 2 distinct segments during the molt to adult. The plane of fusion is marked by a thin and incomplete line on the frontal surface. This scar was erroneously interpreted as a functional articulation by Herbst (1955). Topotypes of $N$. salinarum (Gurney, 1927) examined showed a similar fusion of those segments of leg 4 .

Populations from the Black Sea coast ascribed to $N$. vicinus differ from the Brazilian specimens in a number of morphological details, sufficient to propose that they represent a separate taxon, perhaps $N$. remanei (Herbst, 1952).

A diagnosis for Neocyclops is provided.
\end{abstract}

\section{Résumé}

Redescription de Neocyclops medius Herbst, 1955 et de $N$. vicinus (Herbst, 1955) des eaux interstitielles intercôtidales des plages de sable le long des côtes du Brésil. Le mâle de $N$. vicinus est pour la première fois décrit.

Neocyclops vicinus peut être aisément distingué de $N$. medius par ses branches furcales relativement plus longues, la présence d'un palpe mandibulaire et l'antenne à dimorphisme sexuel.

Les articles 2 et 3 de l'endopodite de la patte 4 sont fusionnés dans les deux espèces. L'article terminal de l'endopodite biarticulé de la patte 4 du copépodite 5 ne devient pas biarticulé pen- dant la mue de ce copépodite; le plan de fusion est marqué par une ligne peu distincte et incomplète sur la surface frontale ligne par erreur interprétée par Herbst (1955) comme articulation fonctionnelle. Des topotypes de $N$. salinarum (Gurney, 1927) examinés, montrent une fusion similaire de ces articles de la patte 4 .

Des populations de la Mer Noire considérées comme appartenant à $N$. vicinus diffèrent des exemplaires du Brésil par plusieurs détails morphologiques, ce qui permet la supposition qu'il s'agirait d'un taxon distinct (peut-être $N$. remanei (Herbst, 1952)).

Une diagnose du genre Neocyclops est donnée.

\section{Introduction}

Neocyclops has been recorded living in coastal and brackish waters, mostly in interstitial waters.

Petkovski (1986) provided the best critical review of the taxonomic position of the 12 species and subspecies of the genus. He confirmed the opinion that Neocyclops should be considered a senior synonym of Eurycyclops Sewell, 1949 and Pareuryte Herbst, 1952, as was definitively proposed by Pleşa (1981). Pesce (1985), Dussart \& Defaye (1985), and Herbst (1986) also accepted Pleşa's proposition. Based on the number of segments comprising the leg 5 exopodite in males, Petkovski (1986) recognized two groups of species, which were considered of subgeneric rank. Species having leg 5 exopodite 2-segmented were included in Protoneocyclops, while those species with leg 5 exopodite 1-segmented were grouped in Neocyclops s. str. The diagnostic character of Protoneocyclops suggested 
by Petkovski corresponds to the ancestral state within the cyclopoids (Huys \& Boxshall, 1991).

Herbst (1986) listed 5 species of Neocyclops from marine interstitial waters. In Brazil, the genus is represented by Neocyclops (Neocyclops) medius Herbst, 1955 and $N$. (N.) vicinus (Herbst, 1955), both from sandy beaches in Ilhabela (State of São Paulo) and in Salvador (State of Bahia). During an intensive and extensive survey of the intertidal interstitial fauna along the coast of the State of São Paulo, the two species were commonly found and a reasonable number of specimens could be collected. In addition, a few specimens of $N$. vicinus were identified from a sample from a sandy beach in Salvador (State of Bahia). Based on this material, the species are redescribed here.

\section{Material and methods}

The interstitial fauna was collected in the intertidal zone of sandy beaches. The interstitial water, collected in holes dug into the beach during low tide, was filtered through a 125 or $200 \mu \mathrm{m}$ mesh, and the animals retained were fixed in $4 \%$ formalin. Harpacticoids and specimens of Halicyclops, Procyclopina, Cyclopina, and Cuipora were collected together with Neocyclops (Lotufo \& Da Rocha, 1991; Lotufo \& Da Rocha, 1993). Granulometric and salinity analyses were carried out only for samples from São Paulo collected by G.R. Lotufo.

Intact specimens were examined in $85 \%$ lactic acid. Dissected parts were mounted in glycerine in slides sealed with glyceel for preparing drawings with a camera lucida on a Leitz Laborlux microscope.

Some of the specimens examined were deposited in the Museu de Zoologia, Universidade de São Paulo (MZUSP), São Paulo. The remaining material is in C.E.F. da Rocha's collection at the Departamento de Zoologia, Universidade de São Paulo.

The terminology applied to body and appendage segmentation follows that of Huys \& Boxshall (1991).

\section{Taxonomy}

Family Cyclopidae Burmeister, 1834

Subfamily Halicyclopinae Kiefer, 1927

\section{Neocyclops medius Herbst, 1955}

(Figs. 1-17)

Holotype not examined.

Material examined. - Brazil, State of São Paulo. Carlos E.F. da

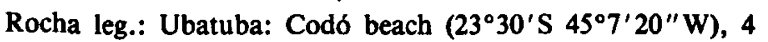
Nov. 1983, 36 \& $\odot$ and $2 \circ \circ$.
Liliana Forneris leg.: Ubatuba, Codó beach, 22 Feb. 1972, 4 १ ९ ; Lamberto beach ( $\left.23^{\circ} 29^{\prime} 55^{\prime \prime} \mathrm{S} 45^{\circ} 7^{\prime} 15^{\prime \prime} \mathrm{W}\right), 25$ Feb. 1972, 2 ○ ९ ; Ilhabela: Siriúba beach $\left(23^{\circ} 45^{\prime} 5^{\prime \prime} \mathrm{S} 45^{\circ} 21^{\prime} 15^{\prime \prime} \mathrm{W}\right), 29$ May $1975,7 \& \&$ and $1 \circ$.

Guilherme R. Lotufo leg.: Ubatuba: Codó beach, 6 July 1991, $20 \propto Q$ and 10 o $\sigma^{\circ}$; São Sabastião: Cigarras beach $\left(23^{\circ} 45^{\prime} 15^{\prime \prime} \mathrm{S} 45^{\circ} 24^{\prime} 45^{\prime \prime} \mathrm{W}\right), 17$ Sep. 1990,1 \% ; São Francisco beach $\left(23^{\circ} 45^{\prime} 30^{\prime \prime} \mathrm{S} 45^{\circ} 24^{\prime} 40^{\prime \prime} \mathrm{W}\right), 17$ Sep. 1990, 2 \% 9 and 2 o $\sigma^{\circ}$; 14 June 1991, $2 \circ \%$ and $2 \sigma^{\circ} \sigma^{\circ}$; Olaria beach $\left(23^{\circ} 46^{\prime} \mathrm{S}\right.$ $\left.45^{\circ} 24^{\prime} 20^{\prime \prime} \mathrm{W}\right), 15$ June 1991, $20 \% \varnothing$ and $13 \circ \sigma^{\circ}$; Arrastão beach ( $\left.23^{\circ} 46^{\prime} 20^{\prime \prime} \mathrm{S} 45^{\circ} 24^{\prime} 15^{\prime \prime} \mathrm{W}\right), 17$ Sep. 1990,1 , ; 11 March

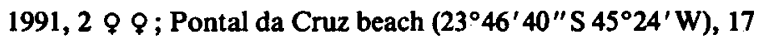
Sep. 1990, 8 $\%$; 11 March 1991, 2 \%; Deserta beach $\left(23^{\circ} 47^{\prime} 5^{\prime \prime S} 45^{\circ} 24^{\prime} 20^{\prime \prime} \mathrm{W}\right), 17 \mathrm{Sep} .1990,3$ \& $\%$; 11 March $1991,1 \sigma^{\circ}$; Calhetas beach $\left(23^{\circ} 49^{\prime} 15^{\prime \prime} \mathrm{S} 45^{\circ} 28^{\prime} 10^{\prime \prime} \mathrm{W}\right), 16 \mathrm{Sep}$. 1990,1 \%; Ilhabela: Pinto beach $\left(23^{\circ} 44^{\prime} 30^{\prime \prime} \mathrm{S} 45^{\circ} 20^{\prime} 52^{\prime \prime} \mathrm{W}\right)$, 10 March 1991, $1 \%$ and $10^{\circ}$; Garapocaia beach $\left(23^{\circ} 44^{\prime} 50^{\prime \prime} \mathrm{S}\right.$ $\left.45^{\circ} 20^{\prime} 50^{\prime \prime} \mathrm{W}\right), 10$ March 1991, 1 \%; Viana beach $\left(23^{\circ} 45^{\prime} 5^{\prime \prime} \mathrm{S}\right.$ 45'21' $\left.50^{\prime \prime} \mathrm{W}\right), 6$ Nov. 1990, 2 \& \&; 10 March 1991, 3 \& Q and

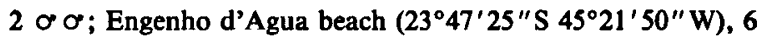
Nov. 1990, 2 \% \%.

Lot of $36 \%$ and $1 \sigma^{\circ}$ from Codó beach and lot of 21 우 and $6 \sigma^{\circ} \sigma$ from Olaria beach, São Sebastião in MZUSP (coll. nrs. 11383 and 11384 , respectively)

Description of female. - Body length $605-700 \mu \mathrm{m}$ $(n=10)$. Prosome: urosome ratio $=1.3-1.4: 1$. Posterior margin of all prosomites and urosomites (except anal somite) smooth (Fig. 1). Genital double somite (Fig. 2) about as long as wide and with lateral expansions bearing spiniform projections at first third. Seminal receptacle as shown in Fig. 2. Anal somite with row of spinules on posterior edge. Pseudoperculum as in N. vicinus (Fig. 19). Caudal rami (Fig. 3) 1.5-1.7 times longer than wide. Dorsal seta 1.7 times longer than outer apical seta. Inner apical seta 1.3 times longer than outer apical seta. All caudal setae plumose.

Labrum (Fig. 4) with 6-10 teeth on free margin.

Antennule (Fig. 5) 12-segmented. Armature as follows (Roman numeral = segment; Arabic numeral = seta; ae = aesthetasc): I - 8; II - 4; III - 2; IV - 6; V - 3; VI - 2; VII - 2; VIII - 3; IX - 2 + ae; X - 2; XI - $2+$ ae; XII - $7+$ ae.

Antenna (Fig. 6) 4-segmented. Basis with 2 inner apical setae. Endopodite segments 1-3 with 1, 5, and 7 setae, respectively. Seta representing exopodite lacking.

Mandible (Fig. 7) reduced to coxa with gnathobase. Palp lacking.

Maxillule (Fig. 8) with enlarged praecoxa bearing 


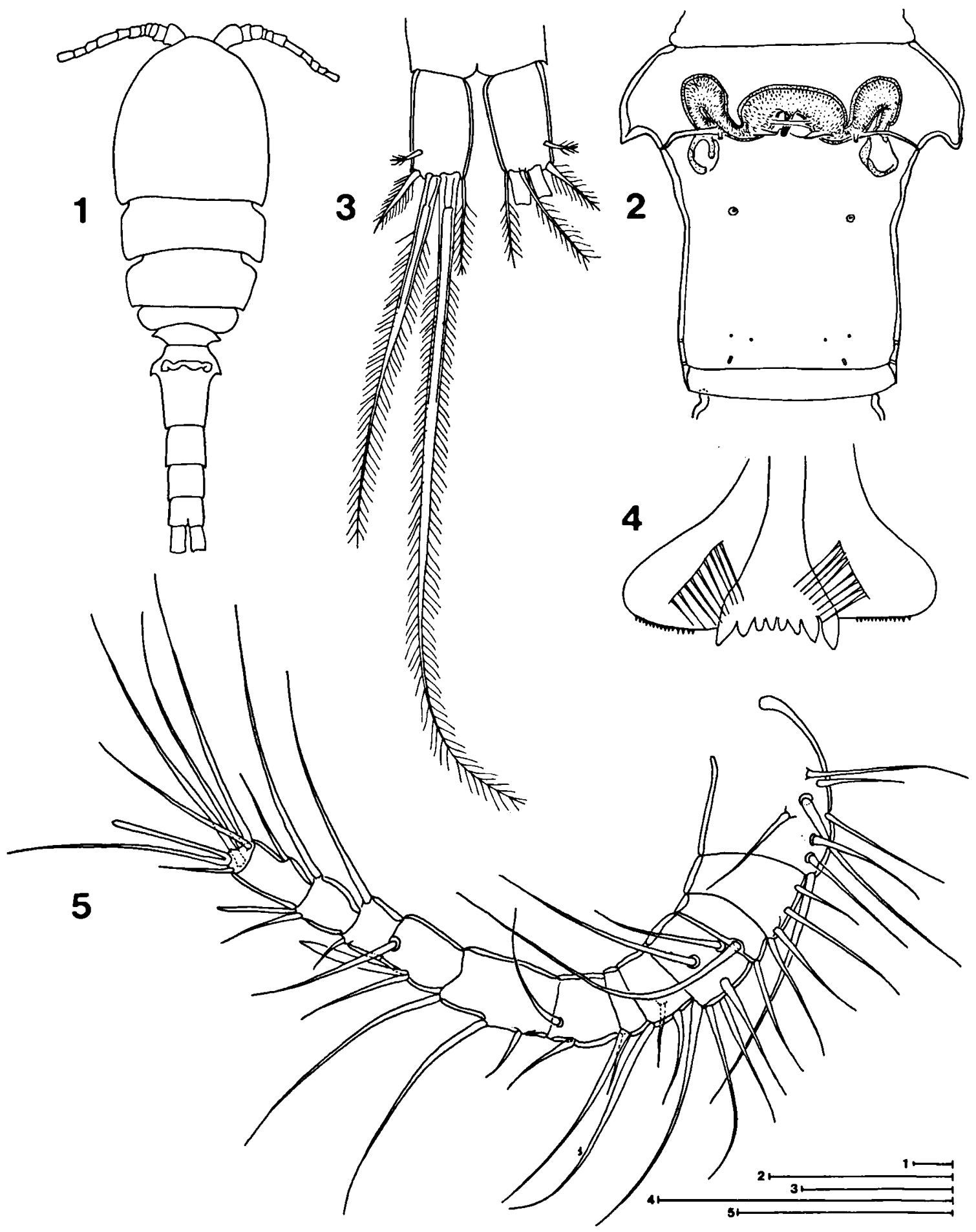

Figs. 1-5. Neocyclops medius Herbst, 1955, \& from Codó beach, Ubatuba: 1, habitus, dorsal; 2, genital double somite, ventral, showing seminal receptacle; 3, caudal rami, dorsal; 4, labrum; 5 , antennule. Scale bars $50 \mu \mathrm{m}$. 


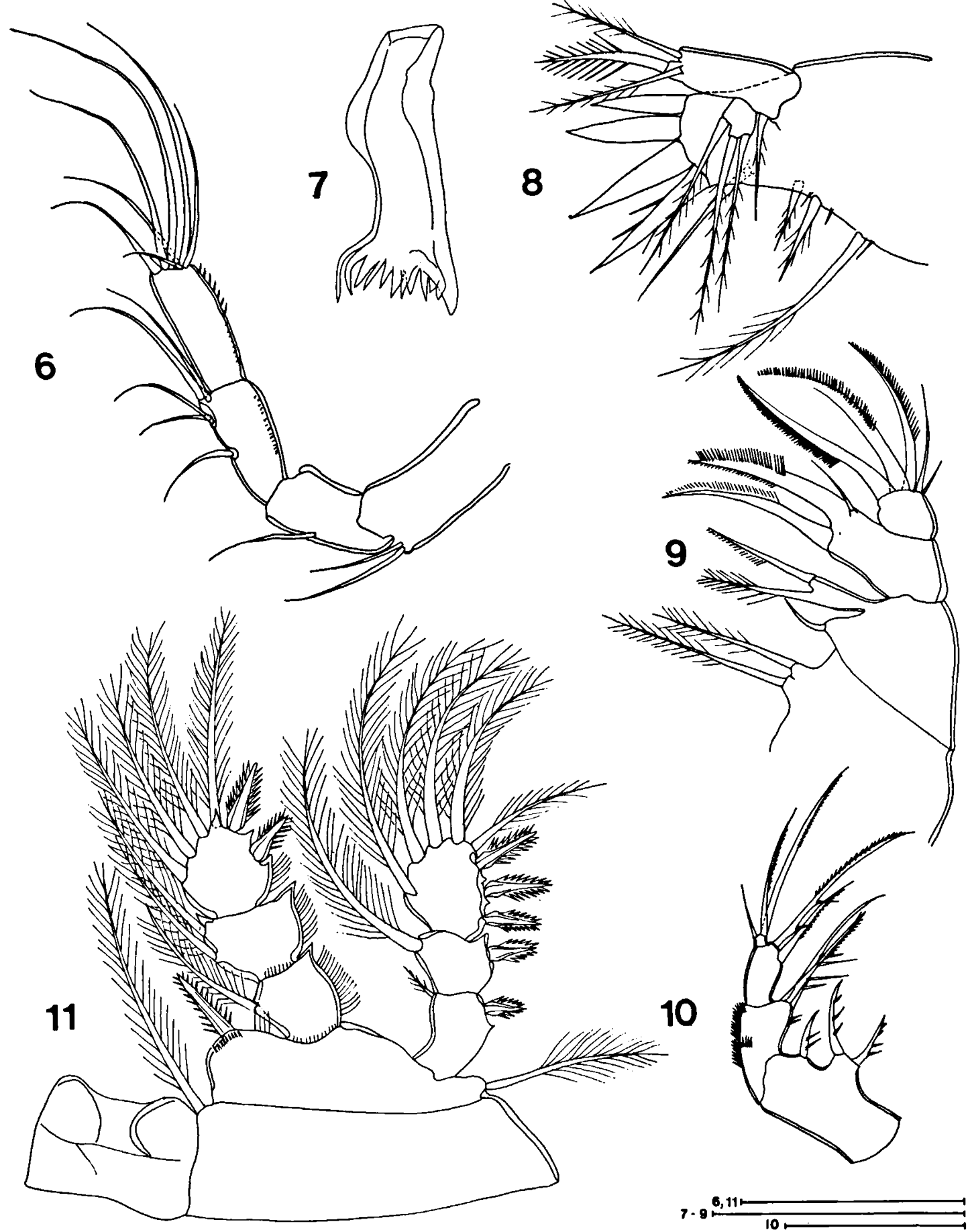

Figs. 6-11. Neocyclops medius Herbst, 1955, \& from Codó beach, Ubatuba: 6, antenna; 7, mandible; 8, maxillule; 9, maxilla; 10, maxilliped; 11, leg 1. Scale bars $50 \mu \mathrm{m}$.

arthrite with 7 setae on inner face and 4 spines on distal margin. Palp consisting of long basis bearing 3 setae on inner margin, 1 proximal seta represent- ing exopodite, and endopodite 1-segmented with 3 setae.

Maxilla (Fig. 9) 4-segmented. Praecoxa bearing 

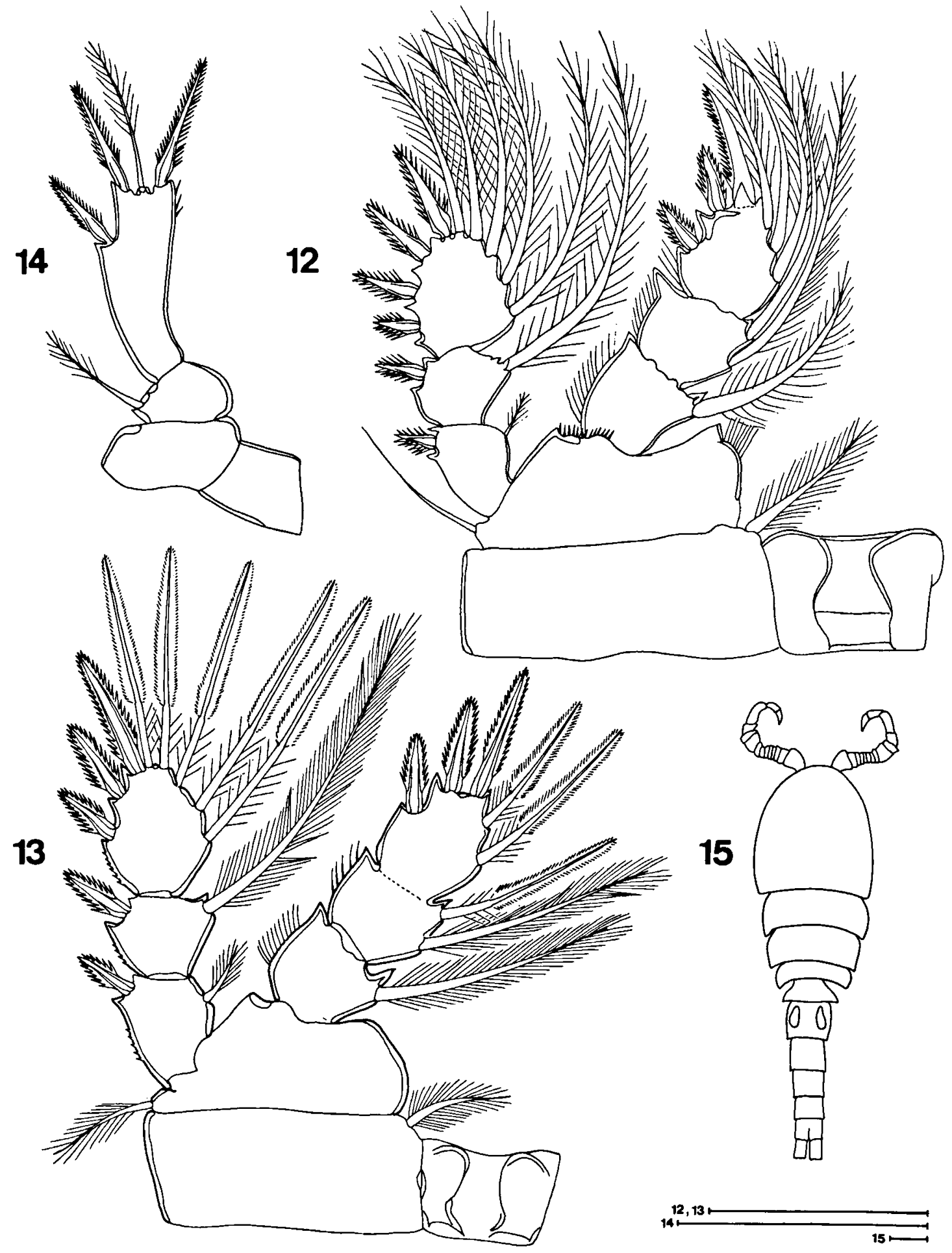

Figs. 12-15. Neocyclops medius Herbst, 1955, from Codó beach, Ubatuba: 12, १ leg 3;13, १ leg 4, caudal face; 14, ơ leg 5; 15, $\propto^{\circ}$ habitus, dorsal. Scale bars $50 \mu \mathrm{m}$. 
endite with 2 setae. Coxa bearing 2 endites, proximalmost with 1 seta and distalmost, enlarged, with 2 setae. Basis drawn out into claw fused to endite, with 1 stout seta longer than claw and 1 reduced seta set basally on claw. Free endopodite 1-segmented with 5 setae.

Maxilliped (Fig. 10) 4-segmented. Syncoxa with 3 setae. Basis with 2 setae. Endopodite 2-segmented, with 2 setae on proximal segment and 3 setae on distal segment.

Legs 1-4 armature as follows (Roman numerals representing spines; Arabic numerals indicating setae):

$\begin{array}{lllll} & \text { Coxa } & \text { Basis } & \text { Endopodite } & \text { Exopodite } \\ \text { Leg 1 } & 0-1 & 1-\mathrm{I} & 0-1,0-2, \text { II-4 } & \text { I-1, I-1, III-5 } \\ \text { Leg 2 } & 0-1 & 1-0 & 0-1,0-2, \text { III-3 } & \text { I-1, I-1, IV-5 } \\ \text { Leg 3 } & 0-1 & 1-0 & 0-1,0-2, \text { III-3 } & \text { I-1, I-1, IV-5 } \\ \text { Leg 4 } & 0-1 & 1-0 & 0-1,0-2, \text { III-2 } & \text { I-1, I-1, III-5 }\end{array}$

Leg 1 exopodite segment 1 (Fig. 11) with very reduced inner seta. Leg 2 differing from leg 3 (Fig. 12 ) in size and in having more slender spines on exopodite. Leg 4 endopodite segments 2 and 3 (Fig. 13) fused, scar visible as thin and incomplete suture only on frontal surface. Leg 4 endopodite segment 2 with 3 inner distal setae, and all setae on exopodite segment 3 modified, being plumose proximally and with hyaline membrane finely serrate distally.

Leg 5 (Fig. 14) 3-segmented, joined by intercoxal sclerite. Coxa unarmed. Basis with 1 plumose outer seta. Terminal segment (exopodite) 3 times longer than wide, with 3 spines shorter than segment and 1 seta; inner apical spine about 1.1 times longer than outer apical spine, and 1.4 times longer than lateral spine.

Description of male (Fig. 15). - Body length $465-520 \mu \mathrm{m}(n=10)$. Prosome : urosome ratio = 1.3 : 1 . Urosome with 6 somites.

Antennule 16-segmented, armed as in N. vicinus (cf. Fig. 22).

Leg 5 (Fig. 16) with 1 inner seta in addition to elements present in female.

Leg 6 (Fig. 17) consisting of serrate inner spine and 2 setae.

The male is identical to the female in all other respects.
Habitat. - Medium and coarse sand (median grain size $300-1150 \mu \mathrm{m}$ ). Salinity ranged from 1 to $32 \%$. Temperature ranged from 20 to $32^{\circ} \mathrm{C}$.

Distribution. - Brazil, State of Bahia: Salvador (type-locality); State of São Paulo: Ubatuba, São Sebastião, and Ilhabela. West Indies: Tortuga, Blanquilla, Los Roques, Margarita, and Bonaire (Pesce \& Galassi, 1993).

Discussion. - The specimens were identified as Neocyclops medius because they agreed with the original description in respect to body shape and length, shape of genital double somite, proportions and armature of caudal rami, absence of mandibular palp, and armature of leg 5 in both male and female.

There are differences between Herbst's (1955) description and the specimens examined here. Herbst represented the leg 4 endopodite as 3-segmented and apparently had no difficulty in observing an articulation between the second and third segments. He did not point it out in the text. In the specimens from our samples, this articulation is seen as a thin and incomplete suture on the frontal surface and is interpreted as the fusion scar between those two segments. No line could be seen on the caudal surface. Examination of the copepodid stages revealed that what actually happens is a failure of division of the terminal segment of the leg 4 exopodite of the copepodite into 2 segments during the molt to adult. If these scars also occurred in Herbst's specimens, one may suppose that he considered them a functional articulation. The transformation of plumose setae into modified ones occurs in the change from copepodid 5 to 6 . Herbst did not represent the distal seta of leg 4 endopodite segment 2, making it impossible to know whether it was modified. He did not represent the short seta on the leg 1 exopodite 1 in his drawings either.

Within Neocyclops, only N. salinarum (Gurney, 1927), the type-species, and $N$. medius have the mandible lacking a palp. Neocyclops salinarum differs from $N$. medius in possessing an antennule of 8 segments and, according to Por's (1973) redescription, in possessing a seta representing the exopodite of the antenna. Examination of speci- 


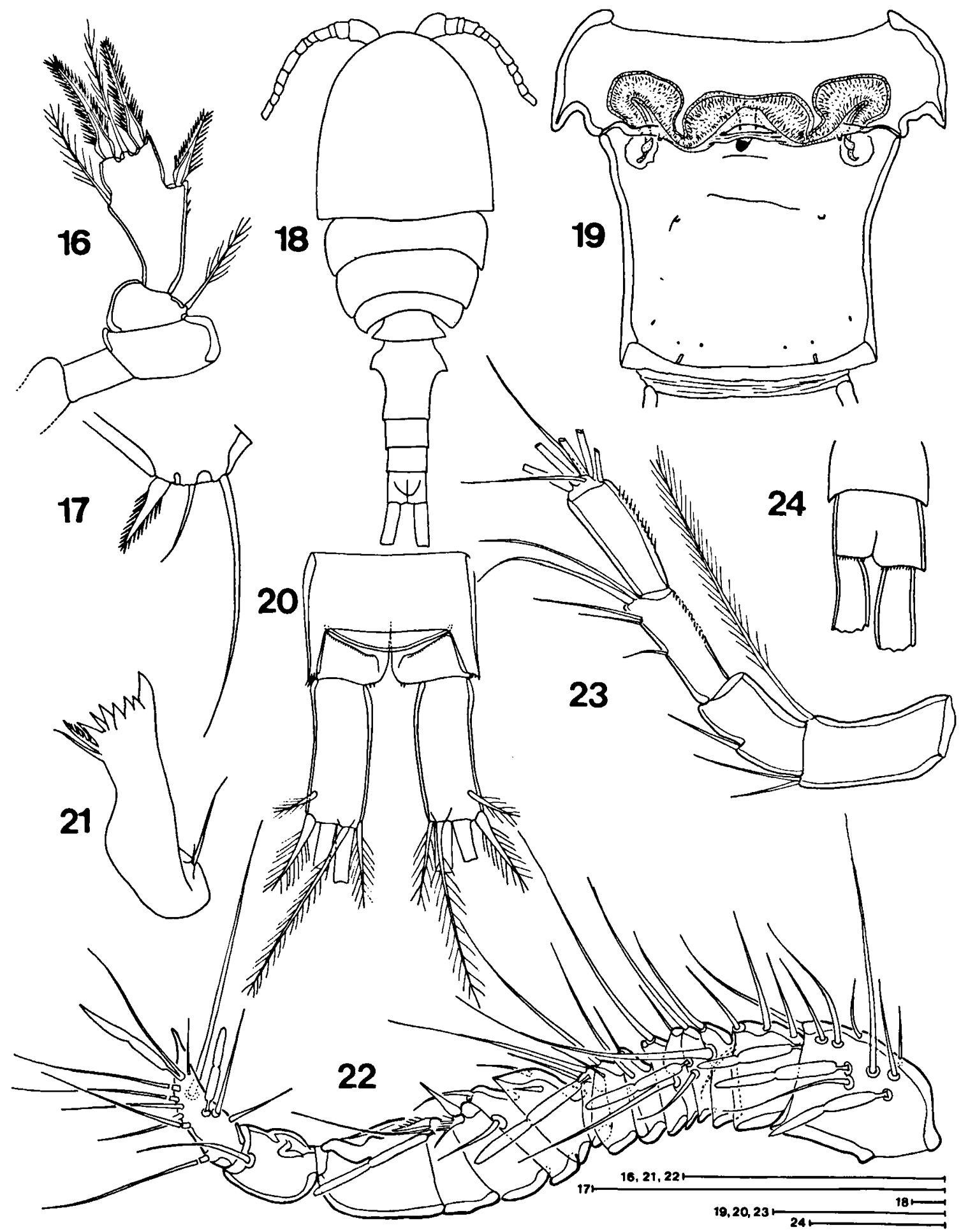

Figs. 16-17. Neocyclops medius Herbst, 1955, ơ from Codó beach, Ubatuba: 16, leg 5; 17, leg 6.

Figs. 18-24. Neocyclops vicinus (Herbst, 1955), from Codó beach, Ubatuba: 18, $\odot$ habitus, dorsal; 19, $९$ genital double somite, ventral, showing seminal receptacle; 20, $९$ anal somite and caudal rami; 21, $९$ mandible; 22, $\sigma$ antennule; 23, ơ antenna; 24, $\sigma^{\circ}$ abnormal caudal rami. Scale bars $50 \mu \mathrm{m}$. 
mens of $N$. salinarum from the Sirbonian Lagoon (Sabkhat and Bardawil), Mediterranean coast of Sinai, kindly provided to us by Dr. F.D. Por, confirmed both the presence of the outer seta on the basis of the antenna in both sexes and a fusion between leg 4 endopodite segments 2 and 3 as observed in our specimens of $N$. medius. Both Gurney (1927) and Por (1973) lapsed in observation by representing the leg 4 endopodite as having 3 segments. The fusion is clearly seen when the articulation between the endopodite segments 2 and 3 of the leg 4 is compared to the actually functional articulations on leg 4, as well as to those on other swimming legs.

\section{Neocyclops vicinus (Herbst, 1955)}

(Figs. 18-24)

Syn. - Pareuryte vicina Herbst, 1955.

Non Eurycyclops remanei vicinus; Pleşa, 1963; Monchenko, 1974; $1975 ; 1979$.

\section{Holotype not examined.}

Material examined. - Brazil, Carlos E.F. da Rocha leg.: State of Bahia, Salvador: Bregari beach (12 $\left.{ }^{\circ} 55^{\prime} \mathrm{S} 38^{\circ} 31^{\prime} \mathrm{W}\right), 4$ Nov. 1985, $2 \% \propto$ and $2 \sigma^{\circ} \circ^{\circ}$. State of São Paulo, Ubatuba: Codó beach $\left(23^{\circ} 30^{\prime} \mathrm{S} 45^{\circ} 7^{\prime} 20^{\prime \prime} \mathrm{W}\right), 4$ Nov. $1983,49 \%$ \% and $2 \sigma^{\circ} \sigma^{\circ}$; São Sebastião: Segredo beach $\left(23^{\circ} 49^{\prime} 38^{\prime \prime} \mathrm{S} 45^{\circ} 25^{\prime} 30^{\prime \prime} \mathrm{W}\right), 6$ July 1983, $4 \%$ and $5 \sigma^{\circ} \sigma^{\circ} ; 7$ July 1983, $6 \%$ and $4 \sigma^{\circ} \sigma^{\prime}$; Peruíbe: Rio Verde beach $\left(24^{\circ} 34^{\prime} \mathrm{S} 47^{\circ} 13^{\prime} \mathrm{W}\right), 30$ Oct. 1984,1 $\%$ and $1 \%$.

Liliana Medeiros leg.: State of São Paulo, Ubatuba: Anchieta Island, Grande beach $\left(23^{\circ} 32^{\prime} 10^{\prime \prime} \mathrm{S} 45^{\circ} 4^{\prime} 20^{\prime \prime} \mathrm{W}\right), 30$ July 1984 , $15 \% \circ$ and $100^{\circ} \circ$.

Guilherme R. Lotufo leg.: State of São Paulo, Ubatuba: Brava do Sul beach $\left(23^{\circ} 30^{\prime} 10^{\prime \prime} \mathrm{S} 45^{\circ} 10^{\prime} 30^{\prime \prime} \mathrm{W}\right), 7$ Oct. 1990, 1 \%; Vermelha do Sul beach $\left(23^{\circ} 30^{\prime} 30^{\prime \prime} \mathrm{S} 45^{\circ} 10^{\prime} 30^{\prime \prime} \mathrm{W}\right), 7$. Oct. 1990, 1 \%; Caraguatatuba: Martim de Sá beach $\left(23^{\circ} 38^{\prime} \mathrm{S}\right.$ $44^{\circ} 23^{\prime}$ '30"W), 5 Nov. 1990, 1 \& ; São Sebastião: Cigarras beach

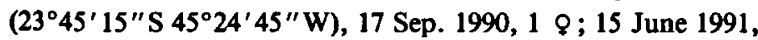
$1 \%$ and $1 \sigma^{\circ}$; São Francisco beach $\left(23^{\circ} 45^{\prime} 30^{\prime \prime} \mathrm{S} 45^{\circ} 24^{\prime} 40^{\prime \prime} \mathrm{W}\right)$, 11 March 1991, $9 \circ \%$ and $5 \sigma^{\circ} \sigma^{\circ} ; 14$ June 1991, $9 \circ \%$ and 3 ơ o'; Olaria Beach $\left(23^{\circ} 46^{\prime} \mathrm{S} 45^{\circ} 24^{\prime} 20^{\prime \prime} \mathrm{W}\right), 15$ June 1991,18 \& $\odot$ and $4 \sigma^{\circ} 0^{\prime}$; Pontal da Cruz beach $\left(23^{\circ} 46^{\prime} 40^{\prime \prime} \mathrm{S} 45^{\circ} 24^{\prime} \mathrm{W}\right)$,

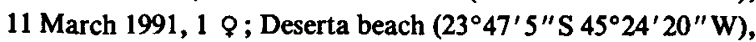
11 Sep. 1990, 1 ९; Porto Grande beach ( $\left.23^{\circ} 47^{\prime} 30^{\prime \prime} \mathrm{S} 45^{\circ} 24^{\prime} \mathrm{W}\right)$, 11 March 1991, 1 \%; Zimbros beach $\left(23^{\circ} 49^{\prime} 25^{\prime \prime} \mathrm{S} 45^{\circ} 25^{\prime}\right.$ $\left.10^{\prime \prime} \mathrm{W}\right), 11$ March 1991, $3 \&$ and $5 \sigma^{\circ} \sigma^{\prime \prime}$; Segredo beach $\left(23^{\circ} 49^{\prime} 38^{\prime \prime S} 45^{\circ} 25^{\prime} 30^{\prime \prime} \mathrm{W}\right), 15$ June 1991, $10 \%$ \% and $10 \sigma^{\circ} \sigma^{\circ}$; 27 July 1991, $12 \propto \circ$ and $5 \sigma^{\circ} \sigma^{\prime}$; Ilhabela: Pinto beach

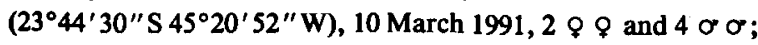
Garapocaia beach $\left(23^{\circ} 44^{\prime} 50^{\prime \prime} \mathrm{S} 45^{\circ} 20^{\prime} 50^{\prime \prime} \mathrm{W}\right), 6$ Nov. 1990,1
9: Barreiros beach $\left(23^{\circ} 45^{\prime} 40^{\prime \prime} \mathrm{S} 45^{\circ} 21^{\prime} 5^{\prime \prime} \mathrm{W}\right), 6$ Nov. 1990, 3 १ १; Pequeá beach $\left(23^{\circ} 47^{\prime} 10^{\prime \prime} \mathrm{S} 45^{\circ} 21^{\prime} 50^{\prime \prime} \mathrm{W}\right), 10$ March $1991,1 \%$ and $1 \sigma^{\circ} ; 27$ July $1991,10 \%$ and $5 \sigma^{\circ} \sigma^{\circ}$; Feiticeiras beach ( $\left.23^{\circ} 49^{\prime} 10^{\prime \prime} \mathrm{S} 45^{\circ} 22^{\prime} 30^{\prime \prime} \mathrm{W}\right), 10$ March 1991,1 \%; Guarujá: Guaiúba beach $\left(24^{\circ} 1^{\prime} 5^{\prime \prime} \mathrm{S} 46^{\circ} 17^{\prime} 45^{\prime \prime} \mathrm{W}\right), 2$ Feb. 1991, $1 \sigma^{\circ}$.

Lot of $30 \% \propto$ and $2 \sigma^{\circ} \sigma$ from Codó beach, Ubatuba, and lot of $15 \% \propto$ and 10 o $\circ$ from Grande Beach, Anchieta Island in MZUSP (coll. nrs. 11385 and 11386, respectively).

Description of female (Fig. 18). - Body length 590-970 $\mu \mathrm{m}(n=10)$. Prosome : urosome ratio = 1.3-1.4: 1. Genital double somite (Fig. 19) as in N. medius. Anal pseudoperculum (Fig. 20) with smooth margin. Caudal rami (Fig. 20) 2.5-3.0 times longer than wide. Dorsal seta 2.2-2.5 times longer than apical seta. Inner and outer apical setae equal in length. All caudal setae plumose.

Labrum similar in general outline to that of $N$. medius, but with 8 to 10 teeth on free margin.

Mandible (Fig. 21) with gnathobase, and palp comprised of 2 setae inserted on reduced lobe.

Antennule, antenna, maxillule, maxilla, maxilliped, and legs 1-5 as in $N$. medius.

Description of male. - Body length 480-600 $\mu \mathrm{m}$ $(n=10)$. Prosome : urosome ratio $=1.3: 1$. Urosome with 6 somites. Some males with abnormal caudal rami (Fig. 24).

Antennule (Fig. 22) 16-segmented, armed as follows (Roman numeral = segment; Arabic numeral $=$ seta; $\mathrm{sp}=$ spine; $\mathrm{ae}=$ aesthetasc): $\mathrm{I}-8+3 \mathrm{ae}$; II - 4; III - 2; IV - 2 + ae; V - 2; VI - 1; VII 2; VIII - 2; IX - $2+$ ae; X - 2; XI - 2; XII $2 \mathrm{sp} ; \mathrm{XIII}-1+\mathrm{sp}+$ ae; XIV $-0 ; \mathrm{XV}-1$; $\mathrm{XVI}-11+2$ ae.

Antenna (Fig. 23) differing from that of female by presence of seta representing exopodite at outer corner of basis, almost reaching tip of antenna.

Leg 6 as in male of $N$. medius.

The male is identical to the female in all other respects.

Habitat. - Medium and coarse sand (median grain size $300-1150 \mu \mathrm{m}$ ). Salinity ranged from 15 to $32 \%$. Temperature ranged from 21 to $32^{\circ} \mathrm{C}$.

Distribution. - Brazil, State of São Paulo: Ilhabela (type-locality), Ubatuba, Caraguatatuba, São 
Sebastião, Guarujá, and Peruíbe; State of Bahia: Salvador. West Indies: Los Roques, Jamaica (Pesce \& Galassi, 1993).

Discussion. - The specimens were identified as $N$. vicinus (Herbst, 1955) because they agreed with the original description in respect to body shape and length, genital double somite shape, caudal rami armature and proportions, armature of leg 5, and presence of 2 setae on the mandibular palp. Just like for $N$. medius, Herbst represented the leg 4 endopodite as 3-segmented, interpreting the scars we observed as a functional articulation. In his drawing, Herbst did not represent the distal seta of leg 4 endopodite segment 2 , present in our material as a modified seta.

Neocyclops vicinus was described as Pareuryte vicina by Herbst (1955). Pleşa (1963) transferred it to the genus Eurycyclops as a subspecies of $E$. remanei (Herbst, 1952). Plesa's new combination was adopted by Monchenko (1974; 1975; 1979). Fortunately, both Pleşa and Monchenko provided descriptive data about females and males they identified from the Black Sea. Females from the Black Sea are larger (body length ranging from 720 to $1100 \mu \mathrm{m}$ ) and possess longer caudal rami (length : width ratio $=2.72-3.48: 1$ ) in relation to the Brazilian females. They also differ from our specimens in having two plumose setae on the inner margin of the leg 4 endopodite segment 2. Monchenko (1975) illustrated the female antenna with short seta representing the exopodite, which was not mentioned by Pleşa (1963).

No author mentioned the existence of sexual dimorphism in the antenna of the Black Sea specimens, a character certainly helpful in making a decision about the identity of these specimens. The differences pointed out here indicate that the Black Sea specimens should be ascribed to another species. They seem to be more closely related to $N$. remanei from the North Sea than to $N$. vicinus.

$N$. vicinus is easily separated from $N$. medius by possessing longer caudal rami, mandibular palp with 2 setae, and sexually dimorphic antenna. It also differs in the shape of the seminal receptacle. On the other hand, $N$. vicinus differs from $N$. remanei in having shorter caudal rami and in lack- ing the seta representing the exopodite of the antenna in the female.

\section{Emendation of diagnosis of Neocyclops}

Neocyclops is defined as follows: antennule of 8 to 12 segments, mandibular palp absent or reduced to a small lobe with 1 or 2 setae, maxilliped with 2-segmented endopodite, leg 4 exopodite segment 3 with all setae modified (plumose at the base and finely serrate on the more distal part of the seta), and the genital double somite expanded at the proximal third. If confirmed for the other species, the fusion of leg 4 endopodite segments 2 and 3 observed in both Brazilian species and in $N$. salinarum can be considered another diagnostic character of the genus.

\section{Acknowledgements}

This research was supported by a grant from Fundação de Amparo à Pesquisa do Estado de São Paulo (FAPESP). We are grateful to the Centro de Biologia Marinha da Universidade de São Paulo and the Instituto Oceanográfico da Universidade de São Paulo for providing logistical support for the fieldwork.

We are also grateful to Dr. Janet Reid for improving the English text and to Dr. Francis Dov Por for providing specimens of Neocyclops salinarum. Mr. Levi Ciobotariu inked the line drawings.

\section{References}

Dussart, B.H. \& D. Defaye, 1985. Répertoire mondial des Copépodes Cyclopoïdes: 1-236 (C.N.R.S., Paris).

Gurney, R., 1927. Zoological results of the Cambridge Expedition to the Suez Canal, 1924. XXXIII. Report on the Crustacea: - Copepoda (littoral and semi-parasitic). Trans. zool. Soc. Lond., 22(6): 451-577.

Herbst, H.V., 1952. Neue Cyclopoida Gnathostoma (Crustacea Copepoda) des Küstengrundwassers. Kieler Meeresforsch., 9(1): 94-111.

Herbst, H.V., 1955. Cyclopoida Gnathostoma (Crustacea Copepoda) von der brasilianischen Atlantikküste. Kieler Meeresforsch., 11(2): 214-229.

Herbst, H.V., 1986. Copepoda: Cyclopoida aus Meeres und Brackwasser-Interstitial. In: L. Botosaneanu (ed.), Stygofauna mundi: 313-320 (E.J. Brill/Dr.W.Backhuys, Leiden). Huys, R. \& G. A. Boxshall, 1991. Copepod evolution: 1-468 (Ray Society, London). 
Lotufo, G.R. \& C.E.F. da Rocha, 1991. Copepods from intertidal interstitial water of Salvador, Brazil. I. Cuipora janaina gen. n., sp. n. \& Cyclopina caiala sp. n. (Cyclopoida: Cyclopinidae). Bijdr. Dierk., 61(2): 107-118.

Lotufo, G.R. \& C.E.F. da Rocha, 1993. Intertidal interstitial Halicyclops from the Brazilian coast (Copepoda: Cyclopoida). Hydrobiologia, 264: 175-184.

Monchenko, V.I., 1974. Cyclopidae. Fauna Ukraïni, 27(3): 1-452, figs. 1-142.

Monchenko, V.I., 1975. Eurycyclops (Crustacea, Copepoda) in fauna of the Soviet Union. Dokl. Akad. Nauk ukr. SSR, (B) 1975(5): 471-477.

Monchenko, V.I., 1979. Marine and brackish Cyclopoida (Crustacea, Cyclopidae) in the Azov-Black Sea basin. Hidrobiol. J., 15(2): 17-20.

Pesce, G.L., 1985. Amsterdam Expeditions to the West Indian Islands, Report 45. Cyclopids (Crustacea, Copepoda) from West Indian groundwater habitats. Bijdr. Dierk., 55(2): 295-323.

Pesce, G.L. \& D.P. Galassi, 1993. Amsterdam Expeditions to the West Indian Islands, Report 74. The genus Neocyclops Gurney in the West Indies: an update including the descrip- tion of Neocyclops (Protoneocyclops) geltrudeae n. sp. Bijdr. Dierk., 63(2): 115-120.

Petkovski, T.K., 1986. Zur Taxonomie des Genus Neocyclops Gurney, 1927 (Crustacea, Copepoda, Cyclopoida). Acta Mus. maced. sci. nat., 18(2): 27-46.

Pleşa, C., 1963. Étude sur la faune interstitielle littorale de la Mer Noire. III. Résultats préliminaires des recherches sur la côte roumaine, avec aperçu spécial sur les Cyclopoïdes Gnathostomes (Crustacea, Copepoda). Vie Milieu, 14(4): 775-813.

Pleşa, C., 1981. Cyclopoïdes (Crustacea, Copepoda) de Cuba. Résultats des Expéditions Biospéologiques Cubano-roumaines à Cuba, 3: 17-34.

Por, F.D., 1973. The benthic Copepoda of the Sirbonian Lagoon (Sabkhat el Bardawil). Cah. Biol. mar., 14: 89-107.

Sewell, R.B.S., 1949. The littoral and semi-parasitic Cyclopoida, the Monstrilloida and the Notodelphyoida. Scient. Rep. J. Murray Exped., 1933-34, 9(2): 17-199.

Received: 29 September 1992

Revised: 26 February 1993 